From the National Veterinary Institute and the Swedish University of Agricultural Sciences, Uppsala, Sweden.

\title{
On the Role of Sawdust in the Development of Mastitis in Cows
}

\author{
By Axel Isaksson and Göran Aström
}

\begin{abstract}
Isaksson, A. and G. Åström: On the role of sawdust in the development of mastitis in cows. Acta vet. scand. 1988, 29, 151-158. - Sawdust was aspirated into one of the teatcups of the milking unit by induced liner slip during milking of 10 cows, which were then slaughtered. Sawdust particles were recovered from the interior of the quarters, the teat skin and the inside of the liners corresponding to both treated and untreated teats, and from the milk claw and the bucket as well. Sterile sawdust was introduced into the teat cisterns of three quarters of one cow. Clinical mastitis developed. The investigation was initiated by an outbreak of Serratia-mastitis in a dairy herd and supports the view that the outbreak was caused by contaminated sawdust used as litter in combination with improper detachment of the milking units. Widening of the impact concept is propsosed.
\end{abstract}

Serratia marcescens; impact.

\section{Introduction}

Sawdust used as litter for dairy herds is easily aspirated into the milking machine and can very often be recovered from the filter of the milk line. The aspiration can take place when a milking unit is being attached or detached, when liner slip occurs and when teatcups spontaneously fall off. This paper presents experimental support for the view that aspirated sawdust, contaminated or not, can be an integral factor in the development of clinical mastitis. The results have been instrumental in clarifying the most likely causes of a unique outbreak of Serratia-mastitis in a dairy herd (Isaksson \& Holmberg 1984).

\section{Material and methods}

The first part of the investigation involved 10 cows sent to the abattoir of Uppsala for slaughter. They were of SRB or SLB (Swed- ish Red-and-White or Swedish Friesian) breed/type, 3-11 years old and in late lactation. They had been milked in their home barns in the morning and were milked again a few hours later in the abattoir with a bucket machine with alternate pulsation. When the end of the milking approached, 2 teaspoons of dry sawdust were poured onto the horizontal part of the collar of one of the liners and the respective teatcup was partly detached for a short moment. The sawdust was instantly aspirated into the teatcup and the milking was finished. The sawdust had in advance been passed through a sieve with a pore diameter of $2.0 \mathrm{~mm}$ in order to remove coarser particles and it had been stained intensively blue with an alcoholic solution of toluidine blue in order to allow safe identification of the aspirated material. Six of the cows had their teats washed by hand after the milking and the water used 
was collected separately from each teat for examination. After air-drying the teats were sprayed with a plastic aerosol (Nobecutan, Astra Meditec) in order to fix to the teat skin the sawdust particles possibly left on the teats.

All cows were slaughtered within $1 / 2 \mathrm{~h}$ after the sawdust treatment. The teats were cut through before the udders were excised from the carcases and the milk still present in the different quarters was tapped out and collected for examination. The udders of 7 cows were brought to the laboratory for further study. In 3 cases the liners, including the short milk tubes, were rinsed out with water which was collected for examination and in 2 and all cases, respectively, the amounts of sawdust in the milk claw and the bucket were recorded.

The collected quarter milk and water were passed through milk filters (for milk lines), which were then cut open and examined for sawdust particles at a magnification at 16 times or more. The teat skin was examined at the same magnification, while the teat canals and the teat and quarter cisterns were usually examined macroscopically only.

Every precaution was taken to avoid transfer of sawdust, after finished milking, between the objects to be examined for the presence of sawdust particles.

In the second part of the investigation 1 Swedish Red-and-White cow was used. She was 4 years old, yielded $17-18 \mathrm{~kg}$ of milk a day, was clinically healthy, and CMT-negative and bacteriologically negative in quarter milk samples taken before the investigation started. Heat-sterilized sawdust was introduced via the teat canal into the teat cisterns of 3 quarters $1 \mathrm{~h}$ after the morning milking. The dose was less than $0.2 \mathrm{~g}$ of sawdust (dry weight). The left fore quarter was treated once in the first week of investigation, the left hind quarter once in the second week and the right fore quarter on 3 consecutive days in the third week. The right hind quarter was left untreated. The cow was controlled clinically and by milk examinations until she was slaughtered 7 weeks after the onset of the investigation. The udder was examined macroscopically in the laboratory.

\section{Results}

The results of the first part of the investigation were as follows. For further quantitative data, see Table 1.

Aspirated sawdust was recovered 10 times from the milk tapped out of the quarters after slaughter, i.e. from the interior of the quarters $(2$ treated and 8 untreated quarters of 5 cows; 10 cows examined) and once from the inside wall of the teat cistern in 1 of the treated quarters.

Other sites of sawdust deposites were observed and were successively recorded during the course of the experimental series. Sawdust was present 20 times in the water used for postmilking teat cleaning (6 treated and 14 untreated quarters; 6 cows examined) and 6 times in the plastic film applied to the teat skin (4 treated and 2 untreated quarters). No sawdust particles were recovered from the teat canals, teat cisterns (one exception) and quarter cisterns (7 cows examined).

The liners corresponding to the treated quarters were heavily, and the other liners more or less, contaminated (the used set examined 3 times). The milk claw and the bucket contained large amounts of sawdust (the used claw and bucket examined 2 and 10 times, respectively).

In the second part of the investgation, the results of the trials were mutually almost identical. Two hours after the introduction of the sawdust into the teat cisterns, the udder was still normal on inspection and palpation, and the milk CMT-negative. The cow 


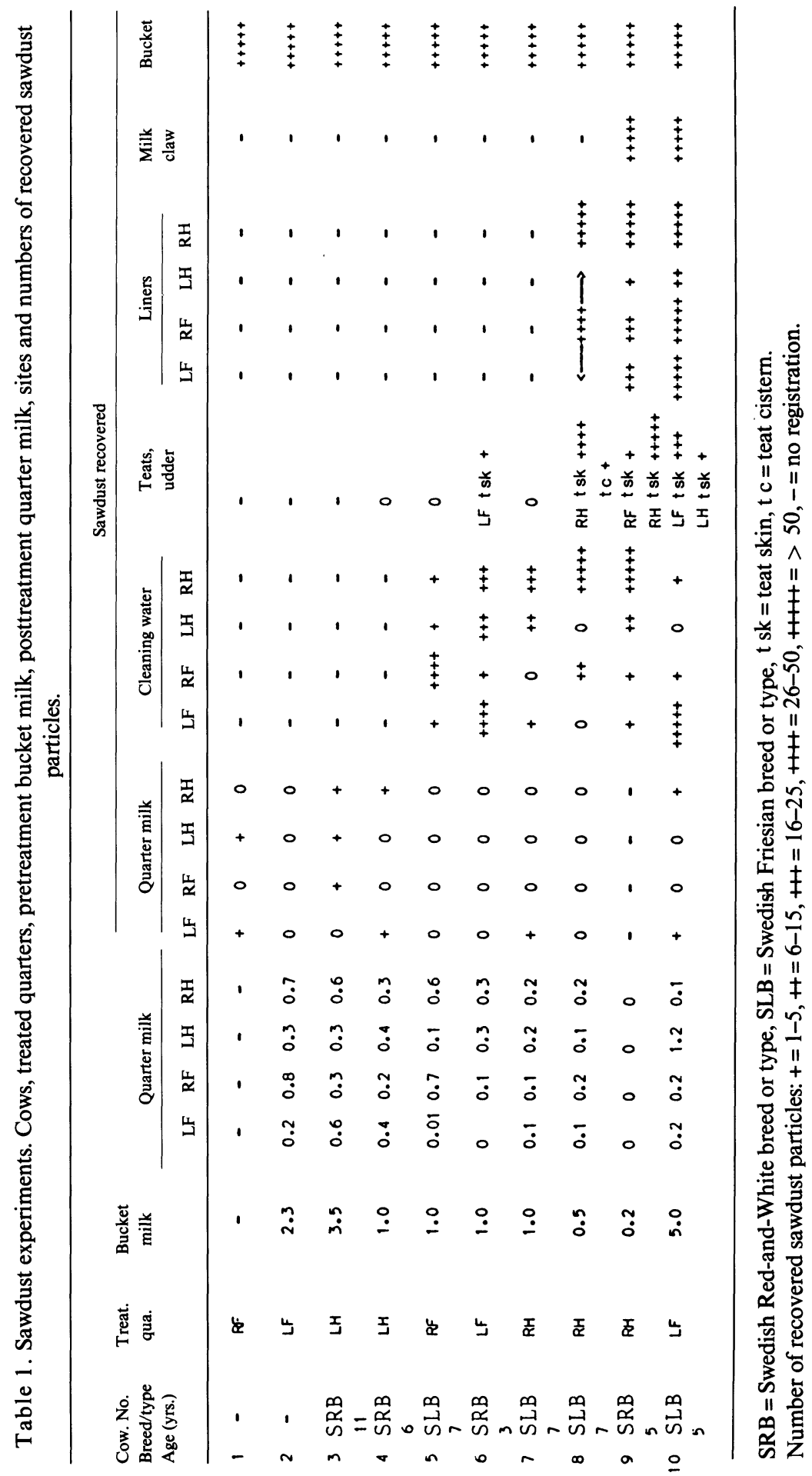


showed no clinical signs of discomfort. Five hours after the introduction, however, the treated quarters especially in their lower parts were swollen, warm, hard and tender. The milk looked normal but the CMT-score indicated several millions of somatic cells $/ \mathrm{ml}$. The body temperature was not raised. The cow was irritated at the first evening milking. Next morning the CMTscore was still high but otherwise the cow behaved normally. Positive CMT-score could persist for a few days and clots containing sawdust particles were occasionally observed when the cow was prepared for milking. There was no obvious difference in the cow's behaviour between treatment of the quarters once and repeatedly. Bacteriological milk examinations were constantly negative and morphological udder examination at the slaughter revealed no macroscopic signs of mastitis.

Some results of the investigation in the Serratia-herd referred to above are presented in the Discussion.

\section{Discussion}

It is generally recognized through research performed mainly in the United Kingdom and the Republic of Ireland (for literature see e.g. Nordegren 1980, Griffin 1984, $O$ 'Shea 1987) that air of atmospheric pressure suddenly rushing down through the teatcups into the milk claw is able to produce, in the claw, aerosols containing milk droplets which can be propelled with high speed and great force backwards through the short milk tubes and, provided open liners are available, against the teat ends and into, and through, the teat canals (impact). Udder pathogens present in the claw and contained in milk droplets or in clots can be introduced by the same route into the quarters. If not immediately rinsed out again, they can become established there and cause infection with subsequent mastitis. Droplets, clots and bacteria can, for natural reasons, also be deposited on the teat skin and on the inner surface of the liners and the short milk tubes. Aerosols caused by liner slip are one of several kinds of reverse milk transport mechanisms which can occur in the milking equipment due to deficiencies in the equipment or in the milking routine and technique.

In the present investigation sawdust particles, aspirated from the liner collar by induced liner slip, could be more or less often recovered from the interior of the quarters, the teat skin, the inside of the liners including the short milk tubes, the milk claw and the bucket. Aerosols containing sawdust (besides milk droplets and possibly clots and bacteria) will in all probability be responsible for the sawdust deposits in both treated and untreated quarters and on the teat skin and the liners of untreated quarters, while the deposits on the skin and the liners of treated quarters, and in the claw and bucket as well, will in the main be due to sawdust particles arrested at their first downward passage. Sawdust particles of suitable size and weight may even be more efficient particles than milk droplets and clots in the bombardment of the teat ends and as carriers of bacteria into the quarters.

The present investigation also demonstrated that clinical mastitis can develop after the introduction of sterile sawdust into the teat cistern. This was not unexpected but the mild course and the short duration could not be foreseen.

The Serratia-herd mentioned in the Introduction usually comprised 40 cows in milk before the disease outbreak. Milking took place in the barn all year round (high milk line, alternate pulsation). In spite of some recruitment the herd was strongly reduced in number during the disease period. The 14 
cows remaining after 21 months of perpetual trouble were slaughtered. Very many episodes of clinical mastitis had then occurred. According to new information (not included in the published report) no less than 160 mastitis cases had been observed in 49 quarters of 32 cows during 13 consecutive months in the middle of the disease period. The fore quarters had been affected 11 times (LF 3 and RF 8 times; $7 \%$ ) and the hind quarters 149 times (LH 76 and RH 73 times; $93 \%$ ). Mastitis in more than one quarter simultaneously had not been seen. The episodes alternated between the quarters but sequencies of 4-7 episodes in the same hind quarter had frequently occurred. And interruptions of the episode series, apparently corresponding to the dry periods of the respective cows, had often appeared.

Usually the episodes had been clinically rather mild and of short duration. They had thus a great resemblance to experimental sawdust mastitis and to the experimental Serratia-mastitis produced by Barnum et al. (1958) and Nicholls \& Barton (1981) as well. No tendency was traced to changes in their clinical appearance over time and there was no inflammatory drying-off of single quarters in the 34 cows, quarter milk samples of which had been examined once or more in the laboratory. Macro- and microscopic examinations of the udders of five cows without acute disease at slaughter revealed nothing except remarkably mild chronic fibrous mastitis without indications of progressive pathologic changes (such as would have been expected in chronic exacerbative mastitis). The mastitis episodes were therefore considered to have been independent of one another even when they repeatedly occurred in the same quarter. The disease was practically resistant to conventional therapy.
Serratia marcescens was the dominating microorganism in examined milk samples. In one series of 56 non-selected samples it was isolated 30 times (after preincubation). Milk samples of all cows in milk were examined twice during the mentioned 13-months period. Four mastitis episodes happened to occur within a week around the samplings. They were all Serratia-negative (no preincubation). Samplings on account of episodes of acute illness in individual cows were not made.

The primary source of the bacteria could not be traced but was in all probability the sawdust used in a thick layer as litter (a sawmill belonged to the farm). Some 30 specimens, representing various food stuffs, water, various parts of the milking equipment (after cleaning only) and other environmental objects including two samples taken at random from used sawdust, had been examined. All samples (no preincubation) were negative in respect of Serratia. However, the microorganism had been recovered in pure culture in other herds using sawdust as litter and the way the sawdust had been stored on the farm (partly outdoor storage) had certainly promoted aerobic bacterial growth.

Serratia marcescens is ubiquitous and usually quite harmless. Mastitis caused by Serratia-infection is rare and an outbreak such as the one in the herd referred to is a unique event (Isaksson \& Holmberg 1984). Examined strains obtained from the herd displayed no unexpected biochemical or other qualities and the cows were ordinary cows without observed signs of increased disposition to mastitis. Attempts at producing experimental Serratia-mastitis were not made but have been done by others (cf. above).

Bacteria and other irritants capable of provoking spontaneous mastitis are usually introduced into the udder through the teat ca- 
nal. The precise mechanisms for the introduction are still largely obscure. In the problem herd the introduction was, however, quite apparently associated with machine milking. The resulting mastitis can thus be classified as belonging to the group of machine-induced mastitis. This term implies that the milking machine in itself and/or the way the machine (more exactly: the milking unit) is handled, have exerted decisive influence on the development of the disease.

The milking equipment in this specific case was 5-6 years old. It had repeatedly been checked during the disease period by a competent technician. No noteworthy technical or other faults resulting from wear and tear, negligence or poor hygiene had been detected. Nor were there any functional insufficiencies provoked by undue demands on the equipment (in relation to the number, flow rate and yield of the simultaneously milked cows). Weak points in this context, but not present in the herd concerned, are small milk claws, insufficient air bleed in the claw, small inner diameter of the milk tubes, great lifting height, weak vacuum pump, small vacuum reserve, too large diameter and rapid movements of the liners, and not-alternate pulsation (McDonald 1975 and others). Thus the milking equipment in itself could not be held responsible for transferring, or even facilitating, the transfer of bacteria and/or other particles to the udder.

Instead the alternative - improper handling of the milking units - could offer a reasonably safe explanation, supported by the results of the experimental investigation, of what had happened in the herd. Details of the milking procedure during the disease period could not be reconstructed but it can be taken for granted that some sawdust had been aspirated into the teatcups, bearing in mind the thick layer of sawdust under the cows. After their aspiration, the sawdust particles, some of them in all probability carrying Serratia bacteria, should have been transferred to the quarters by the same impact forces as after experimental sawdust aspiration. Aspiration leading to mastitis would have been significant only at the moment of detachment of the teatcups when contaminated or uncontaminated sawdust particles introduced into the quarters could not immediately be rinsed out again by the milk flow. Aspiration when the teatcups were being attached, when liner slip occurred or when teatcups spontaneously fell off would have been relatively harmless in this respect. The highly remarkable dominance of hind quarter mastitis should somehow reflect the habitual practice in the order of detaching the teatcups. And the series of mastitis episodes on one and the same side should somehow indicate the influence of the side (right or left) from which the individual cows were milked for a period of time. The effects of the sawdust and the bacteria could not be separated, nor could their relative importance be settled. Each of them can produce mastitis but the disease outbreak accounted for here should have required the combined effect of both. Valuable information in this and other respects would have been gained by: examinations of clots for the presence of sawdust particles, more bacteriological milk examinations during episodes of acute illness and more bacteriological examinations of selected sawdust samples (in both cases preincubated samples), and more detailed knowledge about practiced milking routine and technique.

A few cases illustrating the role the handling of the milking units can have, have been accounted for in the literature. Walsh (1985) reports on clinical mastitis in a herd with 110 cows where the teatcups of the left teats 
were consistently detached about one second earlier than those of the right teats. During the studied period (4 years) 33 cases of clinical mastitis were observed in the left and 70 in the right quarters (32\% versus $68 \%$ ). Griffin et al. (1982) reports on infection in 25 out of 40 quarters in a trial lasting for 2 weeks when the teatcups were less carefully detached and in 7 out of 40 quarters when they were carefully detached $(62 \%$ versus $17 \%)$. The risk of infection was artificially raised during the last phase of the milkings. Barnum et al. (1958) gives an account of Serratia-mastitis in a dairy herd comprising 24 cows. Serratia marcescens was isolated 75 times from 23 quarters of 11 cows during a period of 6 months. From their documentation it can be seen that $25 \%$ of the isolations referred to the fore and $75 \%$ to the hind quarters. The 2 first-mentioned cases are clearly due to the way the milking machines were used, and the third case may belong to the same group.

\section{References}

Barnum DA, Thackeray EL, Fish NA: An outbreak of mastitis caused by Serratia marcescens. Canad. J. comp. Med. 1958, 22, 392395.

Griffin TK: The milking machine and udder infection in dairy cows. Vet. Annual 1984, 24, 94-99.

Griffin TK, Grindal RJ, Williams RL, Neave FK, Westgarth $R$ : Effect of the method of removal of the milking machine cluster on new udder infection. J. Dairy Res. 1982, 49, 361-367.

Isaksson, $A$, Holmberg $O$ : Serratia-mastitis in cows as a herd problem. Nord. Vet.-Med. 1984, 36, 354-360.

McDonald J: Effect of milking machine design and function on new intramammary infection. J. Milk Food Technol. 1975, 38, 44-51.

Nicholls TJ, Barton MG: Serratia liquefaciens as a cause of mastitis in dairy cows. Vet. Rec. 1981, 109, 288.
Nordegren, $S$ - $A$ : Cyclic vacuum fluctuations in milking machines. Thesis 1980. University Hohenheim, Federal Republic of Germany.

$O$ 'Shea $J$ : (in conjunction with IDF Subgroup A2D): Bull. IDF no. 215. Machine milking factors affecting mastitis. A literature review. 1987. Brussels.

Walsh KP: A report on the prevalence of clinical mastitis and the somatic cell distribution associated with machine milking in a one-sided milking parlour. S. Afr. J. Anim. Sci. 1985, 15, 173-175.

\section{Sammanfattning}

Om sågspån $i$ uppkomsten av mastit hos kor.

Sågspån sögs in i en av spenkopparna genom avsiktligt luftinsläpp mellan spengummit och spenväggen under pågående mjölkning av 10 kor. Korna slaktades därefter. Sågspånspartiklar återfanns i juverdelar, spenhud och spengummin hörande till såväl behandlade som obehandlade spenar samt i mjölkningsorganens central och $i$ mjölkspannen (Tabell 1). Uppenbarligen hade en del av spånen transporterats till centralen och därifrån baklänges till spenspetsarna och in genom spenkanalerna, med största sannolikhet medelst aerosoler (s.k. impact). Steril sågspån som applicerades $i$ tre spencisterner hos en ko gav upphov till ganska lindrig och kortvarig klinisk mastit.

Försöken var initierade av observationer i samband med ett utbrott av Serratia-mastit i en mjölkkobesättning (Isaksson \& Holmberg 1984) och stöder uppfattningen att detta utbrott var relaterat till kontaminerad sågspån använd som strö i kombination med sådan hantering av mjölkningsorganen att onormalt stort luftinsläpp och insugning av sågspån förekom vid avtagningen av mjölkningsorganen. De enskilda mastitepisoderna påminde om både experimentella sågspånsmastiter och experimentella Serratia-mastiter.

Denna undersökning kan ge en ny dimension åt den pågående diskussionen om impact. Bakterier tycks kunna införas $i$ en juverdel genom impact inte bara av mjölkdroppar och flockor utan även av miljöpartiklar, t. ex. sågspån, av lämplig storlek och vikt (vektorer) efter föregående insugning av dessa i mjölkningsorganen. Vid sidan av sin roll 
som vektorer synes sådana partiklar även kunna ha självständig betydelse för uppkomsten av mastit och utgöra en aggraverande faktor vid i övrigt infektiösa mastiter. Undersökning av flockor på förekomst av eventuella vektorer torde ibland kunna ge värdefull information.

(Received September 30, 1987).

Reprints may be requested from: National Veterinary Institute, Library, S-750 07 Uppsala, Sweden. 